\title{
CLINICAL STUDY OF PERFORATIONS OF SMALL BOWEL
}

\author{
Gopalakrishna K. $H^{1}$
}

${ }^{1}$ Assistant Professor, Department of General Surgery, Mandya Institute of Medical Sciences, Mandya.

ABSTRACT

\section{BACKGROUND}

Small intestinal perforation is a common abdominal emergency and still have a significant mortality and morbidity. Aim of our study was as follows - 1 . To study the possible risk factors for perforations of small intestine and postoperative complications. 2 . To compare the morbidity and mortality associated with different parts of small bowel.

\section{METHODS}

Patients who presented to Surgical Outpatient Department, Mandya Institute of Medical Sciences, Mandya, with history of pain abdomen on clinical examination and investigations, confirmed case of hollow viscous perforation were subjected to exploratory laparotomy after resuscitation. Intraoperatively confirmed cases of small bowel perforation were included in this study. Study period: Oct. 2012 - Sep. 2015.

\section{RESULTS}

A total number of 49 cases of small bowel perforation admitted in this study period. Out of these 31 cases are of duodenal perforations, 18 cases of ileal perforation. In our study, male outnumbered the female in ratio of 11.2:1. Duodenal ulcer perforation was commonest type of small intestinal perforation found in most of the patients. Pain abdomen and vomiting found in most of the patients. Commonest cause of small intestine perforation was peptic ulcer and typhoid. Ileal perforation has got more mortality and morbidity than duodenal perforation.

\section{CONCLUSION}

In our study, youngest age of small intestine perforation was 14 years and oldest was 70 years. Main presenting complaint was pain abdomen, vomiting, fever and distension of abdomen. Erect abdomen X-ray showed gas under diaphragm in all cases. Postoperative complications are more in ileal perforation than DU perforation. Mortality was more in ileal perforation due to late presentation, malnutrition, anaemia and more interval between perforation and operation. Risk factors for perforations were smoking, tobacco, alcohol and NSAID'S.

\section{KEYWORDS}

Duodenal Ulcer Perforation; Peptic Ulcer Disease; Enteric Perforation; Typhoid Fever.

HOW TO CITE THIS ARTICLE: Gopalakrishna KH. Clinical study of perforations of small bowel. J. Evolution Med. Dent. Sci. 2016;5(60):4154-4160, DOI: 10.14260/jemds/2016/949

\section{INTRODUCTION}

Small intestine perforation is a common abdominal emergency faced by general surgeon. Perforation of a small bowel form wide variety of causes comprises the major portion of emergency surgical admissions. The diagnosis and treatment of small bowel perforation remains main problem in our country. Improved medical and surgical care has reduced the scene in North America and U.K., where vascular lesions and malignancies are predominant cause of perforations, while in our country peptic disease, typhoid, tuberculosis are still the common causes. A small bowel perforation carries a high degree of mortality and morbidity.

Generally, in duodenum anterior ulcer perforates and posterior ulcer bleeds. ${ }^{1}$ Typhoid ulcer perforations are in distal ileum. Tuberculosis also commonly affects ileum, proximal colon and peritoneum. A study conducted by SK Nair. $^{2}$ et al (1981) on non-traumatic intestinal perforation, over a period of 1 and $1 / 2$ years.

Financial or Other, Competing Interest: None.

Submission 29-01-2016, Peer Review 24-02-2016,

Acceptance 29-02-2016, Published 26-07-2016.

Corresponding Author:

Dr. Gopalakrishna K. $\mathrm{H}$,

Assistant Professor

Department of General Surgery,

Mandya Institute of Medical Sciences,

Mandya.

E-mail: drgopala566@gmail.com

DOI: 10.14260/jemds/2016/949
All except two cases of enteric perforations were emergency admissions. Out of 50 an exploratory laparotomy was done in 47 , in two cases peritoneal drainage was done and in one case no operative procedure was carried out. Enteric fever was the commonest cause of perforation, tuberculosis was second most common cause of perforation. Most of the patients were in 2nd and 3rd decade of their life. The youngest was a boy of 14 years and oldest was a man of 62 yrs. Males outnumbered females in a ratio of 2.3:1. Majority of cases had solitary perforation in small bowel. Mortality was directly related to perforation operation interval. Average hospital stay was 21.6 days among the survivors. Twenty out of fifty cases studied, died giving an overall mortality of $40 \%$.

J Koumane. ${ }^{3}$ et al (2004) studied 64 cases of typhoid ileal perforation between May 95 and July 98 with an average age of 34 yrs. (5 to 63 yrs.). Postoperative complications were observed in 59 patients (88\%). The mean hospital stay was 30 days. Overall postoperative mortality was $34 \%$ of all postoperative complications, digestive fistula remains the most threatening, because it is likely to generate high morbidity and mortality.

In 1997 Sachin Talawar. ${ }^{4}$ et al reported perforation of the bowel is the most complication of typhoid. Early surgeon and thorough peritoneal lavage provides primary closure with omental graft, resection and anastomosis. The mortality was least with early primary closure of the perforation. Patients with postoperative faecal fistula had higher mortality rates. 
In a study conducted by ARK Adensunkanami. ${ }^{5}$ et al (1997) reported that late presentation, delay in operation, multiple perforations and drainage of copious quantities of pus and faecal material from peritoneal cavity adversely affected the incidence of faecal fistula and mortality rate. The development of faecal fistula significantly affected the mortality rate. Fourteen patients (28\%) died within ten days of operation.

ND Swadia. ${ }^{6}$ et al (1979) recorded 3.77\% incidence of enteric ileal perforation. Wound infection (55.5\%) and toxaemia (26\%) are most common complication and recorded mortality rate of $28.84 \%$ treated operatively and $66.6 \%$ who treated by non-operatively.

P.G. Purhoit.7 (1978) reported a $0.5 \%$ of perforation of small bowel out of 10,000 typhoid patients reported from Sangli epidemic, 41 patients were treated surgically. There was a mortality of $14.6 \%$. This low mortality was due to early reference to hospital and early prompt treatment.

Egglesten. ${ }^{8}$ (1980) reported ileotransverse colostomy as the treatment of choice has less postoperative complications than simple closure of perforation (74\%). Faecal fistula were a major cause of death in $4(31 \%)$ of the 13 patients who died after simple closure, whereas this was the case in only (8\%) of the patients who died after Transverse Colostomy (TC).

In 1970 Charles. ${ }^{9}$ reported giant benign duodenal ulcer have got higher perforation rate $(10-15 \%)$ and advocated definitive treatment.

VJ Pattanakar. ${ }^{10}$ (1966) reported multiple ileal diverticula associated with perforation and peritonitis. Treatment is usually operative intervention and resection of the affected ileum. The prognosis after operation was good.

FC Egglesten. ${ }^{11}$ (1979) has reported incidence of enteric perforation was $5.3 \%$ approximately half of the perforation occurred during second and third week of illness. Majority of patients presented with fever, sudden increase in abdominal pain associated with vomiting. Overall mortality was 32\%. In the majority of patients, it was impossible to ascribe a single cause of death other than that of severe sepsis.

E. Q. Archampong. ${ }^{12}$ (1969) reported mortality of enteric perforation $29.8 \%$. The commonest cause of death was toxaemia leading to peripheral circulatory failure.

Naaya.13 (2004) reported 9.2\% of patients had typhoid perforations; $14 \%$ of patients have died among those perforated. High rate of mortality was noted, among those have multiple perforations requiring resection and anastomosis.

Charles N Mock.14 (1992) indicated that typhoid ileal perforation remains a frequently fatal illness in developing world. The overall mortality rate of $31 \%$ was worsened by extremes of age. Double layer closure of perforation lowered the mortality rate compared with single layer closure

Jain K. ${ }^{15}$ and Saxena AK indicated a technique of omental plugging for large duodenal perforations is safe and fast and can be carried out in poor risk patients; $12 \%$ of patients had preoperative leak who has undergone omentopexy (Graham's patch), whereas there were no postoperative leakage in patients undergone omental plugging.

Risk factors are mainly immunosuppression, smoking, alcohol, tobacco chewing and poor management of enteric fever. The main aim of treatment is to control sepsis and treat the underlying cause. Surgery plays important role in the management of perforations.
This clinical study is undertaken to find the various cause of small intestine perforations and various modes of presentations, the possible risk factors for perforations and postoperative complications.

\section{OBJECTIVES}

1. Study the possible risk factors for perforations of small intestine and postoperative complications.

2. Compare the morbidity and mortality associated with perforations of different parts of small bowel and different aetiologies.

\section{MATERIALS AND METHODS}

Forty nine cases of small bowel perforation have been studied in detail during the period from Oct. 2012 to Sept. 2015. The cases were from the Mandya Institute of Medical Sciences, Mandya. The clinical diagnosis is confirmed by investigations followed by laparotomy formed the basis of selection of cases.

\section{The Investigations were Blood for $\mathrm{Hb} \%$, TC, DC and ESR.}

1. Urine for Albumin, Sugar, Microscopy.

2. Erect abdomen X-ray.

3. Random blood sugar, Blood Urea, Serum creatinine.

4. Serum electrolytes, Widal test in suspected enteric perforation.

\section{Exclusion Criteria}

Small intestinal perforation due to blunt or penetrating trauma were excluded.

In all cases the monitoring of vital signs, preoperative correction of fluid and electrolyte imbalance was done. Exploratory laparotomy was done under GA/SA in all cases. Paramedian incision-upper, mid or lower, was made depending on the suspected site of perforation. Viscera were inspected carefully, the site of perforation located and appropriate procedure was performed, peritoneal lavage (Wash) given with normal saline and peritoneal cavity was drained. Postoperatively, patients were put on continuous nasogastric aspirations, IVF and antibiotics. Recovery was observed in the patients and any complications occurred during the course were noted.

\section{OBSERVATIONS AND RESULTS Age Group}

\begin{tabular}{|c|c|c|}
\hline Age & No. of Patients & Percentage (\%) \\
\hline$<20$ & 8 & 16 \\
\hline $21-40$ & 13 & 26.5 \\
\hline $41-60$ & 20 & 41 \\
\hline$>60$ & 8 & 16 \\
\hline Total & $\mathbf{4 9}$ & $\mathbf{9 9 . 5}$ \\
\hline
\end{tabular}




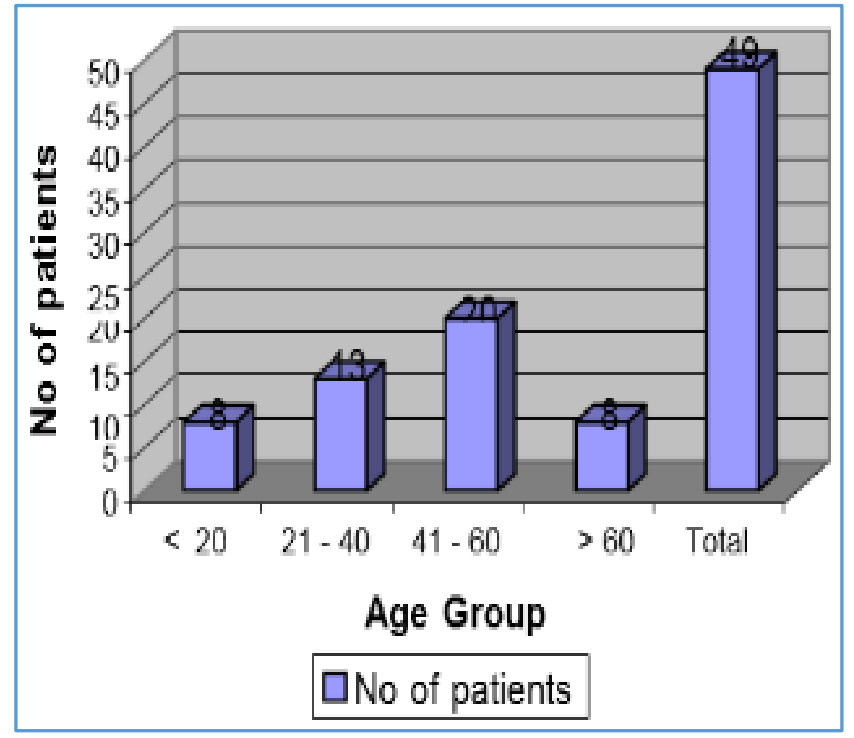

Graph 1

There were (8) eight patients in the age group of $<20$ yrs. constituting $16 \%$ of total perforations of small bowel. Maximum number of cases was found in 41-60 years accounting for $41 \%$. In age group 21-40 yrs., these were 13 cases $(26.5 \%)$ and only 8 cases in age group of $>60$ years.

\section{Sex Distribution}

\begin{tabular}{|c|c|c|}
\hline Sex & No. of Patients & Percentage (\%) \\
\hline Male & 45 & 91.8 \\
\hline Female & 04 & 08 \\
\hline Total & $\mathbf{4 9}$ & $\mathbf{9 9 . 8}$ \\
\hline \multicolumn{3}{|c|}{ Table $\mathbf{2}$} \\
\hline
\end{tabular}

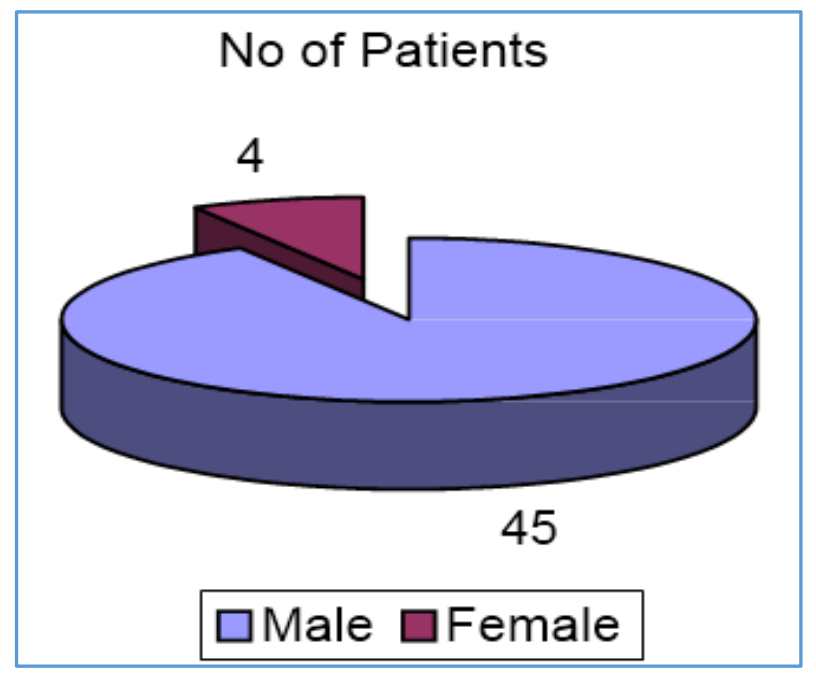

Graph 2

In this study, there was 45 male patients $(91.8 \%)$ and 4 female patients (8\%). There were 2 females in ages between 21-40 years. One female patient was 70 years old having duodenal perforation and other one 15 years old having typhoid ileal perforation.

\section{Site of Perforation}

\begin{tabular}{|c|c|c|}
\hline Sites & No. of Patients & Percentage \% \\
\hline Duodenum & 31 & 63.3 \\
\hline Ileum & 18 & 36.7 \\
\hline Total & $\mathbf{4 9}$ & $\mathbf{1 0 0 \%}$ \\
\hline \multicolumn{3}{|c|}{ Table 3 } \\
\hline
\end{tabular}

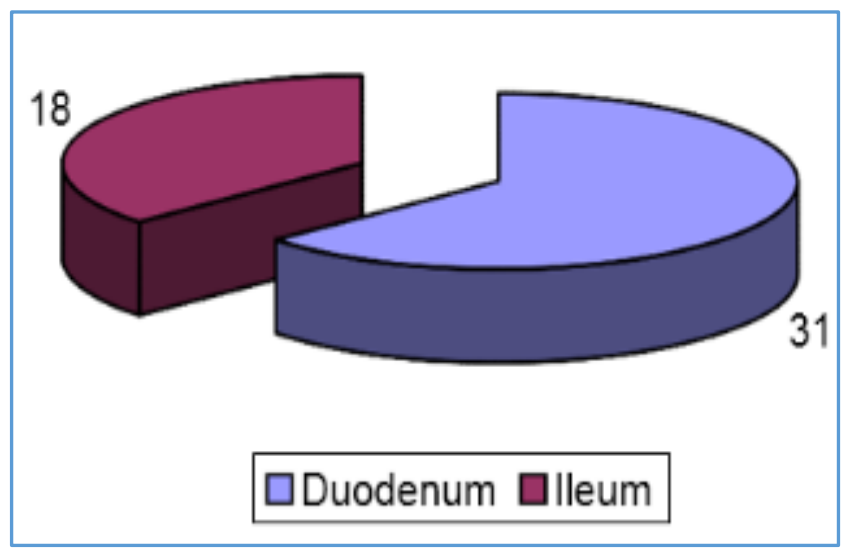

Graph 3

31 patients presented with duodenal ulcer perforation constituting $63.3 \%$ of total small bowel perforation. Ileal perforation was present in 18 patients (36.7\%), out of this 15 patients were having perforation due to typhoid.

\section{Relation between Sex and Site of Perforation}

\begin{tabular}{|c|c|c|c|}
\hline Sex & Duodenum & Ileum & Jejunum \\
\hline Male & 29 & 16 & 0 \\
\hline Female & 02 & 02 & 0 \\
\hline Total & $\mathbf{3 1}$ & $\mathbf{1 8}$ & $\mathbf{0}$ \\
\hline \multicolumn{4}{|c|}{ Table $\mathbf{4}$} \\
\hline
\end{tabular}

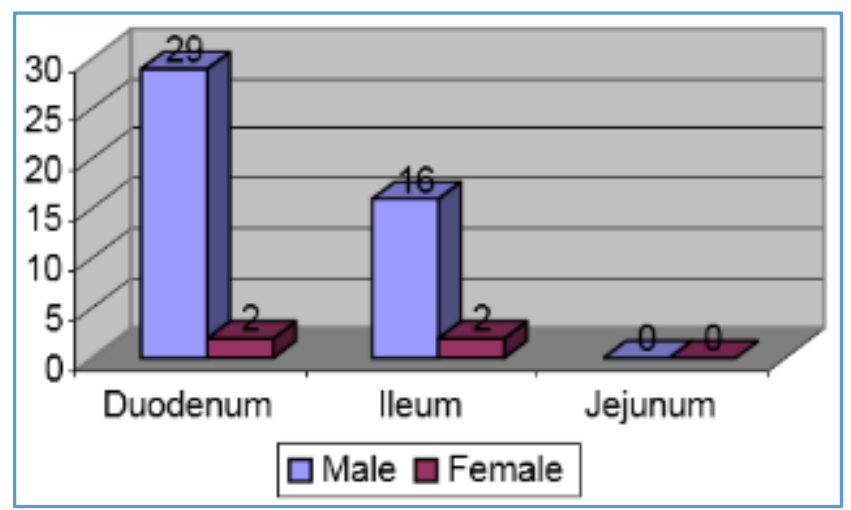

Graph 4

Out of 46 male patients 29 had duodenal perforations (63.04), 16 had ileal perforation where Jejunal perforation was not reported. Duodenal perforation was the commonest cause of small bowel perforation. Among female patients, 2 had duodenal perforation and 2 had ileal perforation. 
Relation between Age and Site of Perforation

\begin{tabular}{|c|c|c|c|c|}
\hline Age & Duodenum & Ileum & Jejunum & Total (\%) \\
\hline$<20$ & 02 & 06 & 0 & $8(16.3)$ \\
\hline $21-40$ & 08 & 05 & 0 & $13(26.5)$ \\
\hline $41-60$ & 14 & 06 & 0 & $20(40.8)$ \\
\hline$>61$ & 07 & 01 & 0 & $8(16.3)$ \\
\hline Total & $\mathbf{3 1}$ & $\mathbf{1 8}$ & $\mathbf{0}$ & $\mathbf{4 9}(\mathbf{9 9 . 9 )}$ \\
\hline \multicolumn{5}{|c|}{ Table 5 } \\
\hline
\end{tabular}

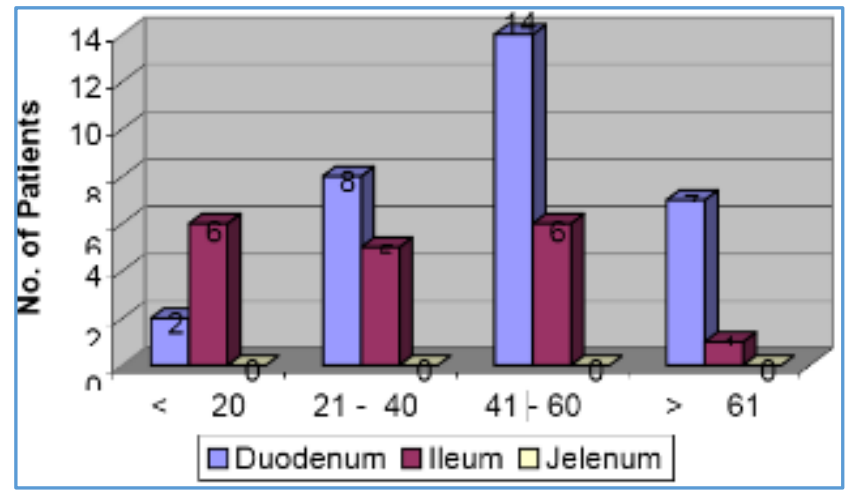

Graph 5

In the age group $<20$ years, there were 2 patients having duodenal perforation and 6 patients had ileal perforation.

In age group 21-40 years duodenal ulcer perforation was in 8 patients, ileal perforation was in only 5 patients.

In 41-60 years duodenal perforation was presenting in 14 patients, whereas ileal perforation was present in 6 patients.

Highest numbers of cases were found in 41-60 years of age. More than 60 years of age, 8 cases were presented in this study.

\section{Symptoms, Signs and Site of Perforation}

\begin{tabular}{|c|c|c|c|}
\hline Signs & Duodenum & Ileum & Jejunum \\
\hline Hypotension & 05 & 04 & 0 \\
\hline Tachycardia & 05 & 04 & 0 \\
\hline Distension & 15 & 18 & 0 \\
\hline Guarding & 29 & 18 & 0 \\
\hline Rigidity & 29 & 18 & 0 \\
\hline $\begin{array}{c}\text { Obliteration of liver } \\
\text { dullness }\end{array}$ & 29 & 17 & 0 \\
\hline \multicolumn{3}{|c|}{ Table 6 } \\
\hline
\end{tabular}

\section{In Duodenal Perforation}

Pain abdomen was the presenting symptom in all cases. Initial pain was present in upper part of abdomen in most of the cases, but in some cases it was generalized abdominal pain. Vomiting was present in majority of patients. Tachycardia and hypotension was present in 5 cases. Guarding and rigidity was present in almost all cases. Obliteration of liver dullness was present in 29 cases, i.e. 93\%. Absent bowel sound present in all cases.

\section{In Typhoid Perforation}

Almost all typhoid-perforation patients had fever. All had fever of more than 15 days. They presented with pain abdomen. Guarding and rigidity present in all patients. Widal test was +ve in 15 cases; 3 cases with Widal test was negative. Distension of abdomen was present in all cases.

\section{Duration}

The duration of symptoms in various patients was as follows.

\begin{tabular}{|c|c|c|}
\hline Duration & No. of Cases & Percentage (\%) \\
\hline $0-12$ hrs. & 03 & 06 \\
\hline 13-23 hrs. & 00 & - \\
\hline $24-48$ hrs. & 28 & 57 \\
\hline$>48$ hrs. & 18 & 36.7 \\
\hline \multicolumn{3}{|c|}{ Table 7 } \\
\hline
\end{tabular}

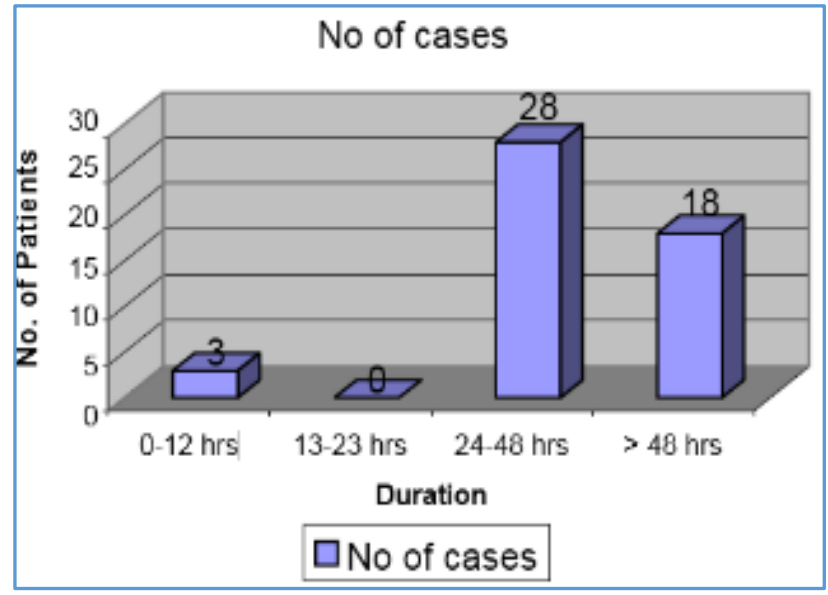

Graph 7

Duration of symptoms depending on site of perforations.

\begin{tabular}{|c|c|c|c|}
\hline Duration & Duodenum & Ileum & Jejunum \\
\hline 0 -12 hrs. & 02 & 01 & 00 \\
\hline $13-23$ hrs. & - & - & - \\
\hline $24-48$ hrs. & 16 & 12 & - \\
\hline$>49$ hrs. & 13 & 05 & 00 \\
\hline \multicolumn{4}{|c|}{ Table 8 } \\
\hline
\end{tabular}

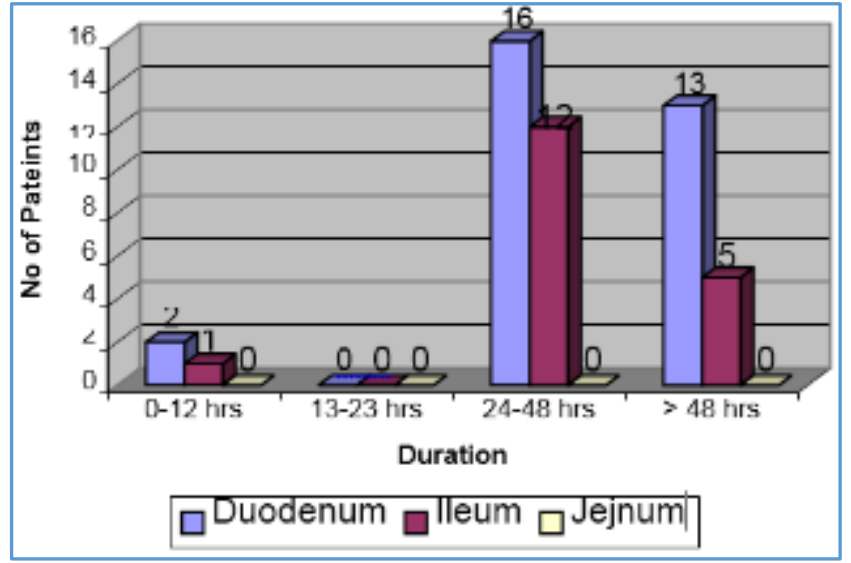

Graph 8

\section{Duration}

Duodenum Ileum Jejunum. 
In this study, there were 3 patients presented within 12 hours of onset of symptoms. Out of these 3, two were duodenal perforation and one was ileal perforation.

28 patients were presented between 24-48 hours (57\%), out of these 16 were duodenal perforation and 12 were ileal perforation; 18 patients were presented after 49 hours of symptoms (36.7\%), out of these 13 patients were with duodenal perforation; 5 were ileal perforation. In this study, most of the patients were presented after 24-hour (47 cases, 93.8\%).

\section{Erect Abdomen X-Ray}

\begin{tabular}{|c|r|r|}
\hline D.U. perforation & 31 & $100 \%$ \\
\hline Ileal perforation & 18 & $100 \%$ \\
\hline \multicolumn{3}{|c|}{ Table 9 } \\
\hline
\end{tabular}

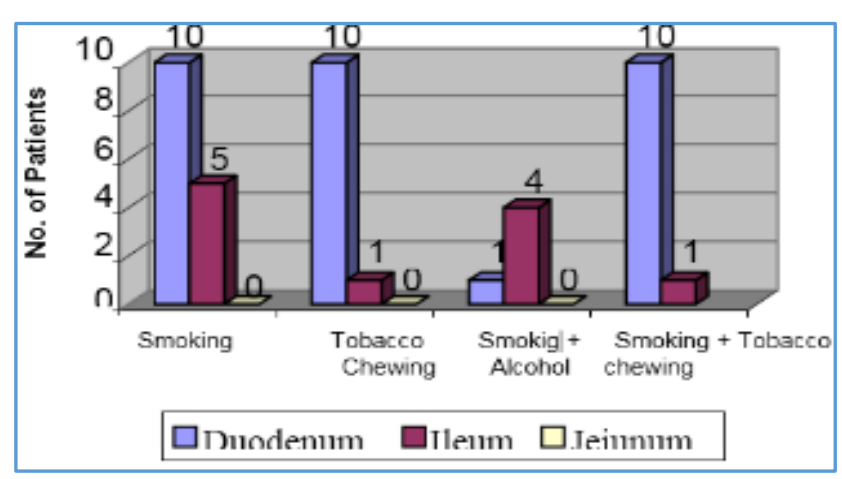

Graph 9

In this study X-ray, erect abdomen was an important investigation to detect gas under diaphragm. All the 31 cases of D.U. perforations were showed gas under diaphragm. Out of 18 ileal perforations, 17 cases were shown gas under diaphragm.

\section{Risk Factors}

\begin{tabular}{|c|c|c|c|}
\hline & Duodenum & Ileum & Jejunum \\
\hline Smoking & 10 & 05 & - \\
\hline Tobacco chewing & 10 & 01 & - \\
\hline Smoking + Alcohol & 01 & 04 & - \\
\hline $\begin{array}{c}\text { Smoking + Tobacco } \\
\text { chewing }\end{array}$ & 10 & 01 & \\
\hline \multicolumn{3}{|c}{ Table 10 } \\
\hline
\end{tabular}

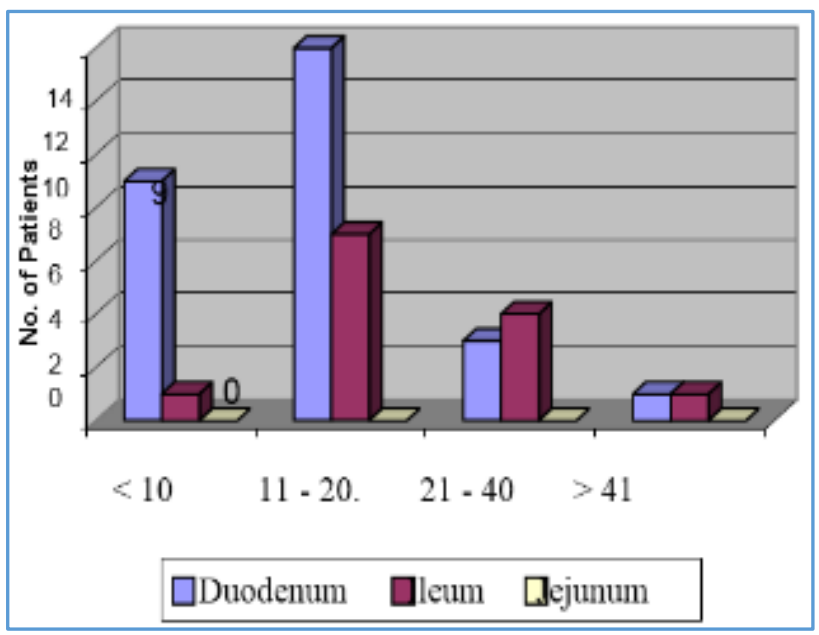

Graph 10
In this study, hospital stay was ranged from 8 days to 68 days. It was less than 10 days for 10 patients; 22 patients stayed in hospital in between 11-20 days; 7 patients had stayed between 21-40 days; 2 patients stayed more than 41 days (i.e. 58 days and 68 days). These two patients had burst abdomen. One patient had respiratory infection and wound infection.

\section{Mortality and Morbidity}

\begin{tabular}{|c|c|c|c|c|c|c|}
\hline & \multirow{2}{*}{ Mortality } & \multicolumn{5}{|c|}{ Morbidity } \\
\cline { 3 - 7 } & WI & RI & BA & ECF & WI+RI \\
\hline Duodenum & 4 & 7 & 8 & 1 & 1 & 4 \\
\hline Ileum & 5 & 6 & 5 & 2 & 1 & 4 \\
\hline \multicolumn{7}{|c|}{ Table 11 } \\
\hline
\end{tabular}

\section{Morbidity}

In duodenal perforation, postoperative complications were present in 21 patients (67\%). Morbidity was in the form of wound infection in 7 patients $(23 \%)$. Respiratory infection was found in 8 patients (25\%). Burst abdomen and enterocutaneous fistulae found in one each patient $(3 \%$ each); 4 patients had both respiratory infection and local wound infection (12\%).

In ileal perforation, most of the patients had postoperative complications like wound infection in 5 patients (27\%), 2 cases had burst abdomen (11\%), 1 case had enterocutaneous fistulae (5\%).

4 patients were having both wound infection and respiratory infection (22\%).

\section{Mortality}

In this study, total 9 patients have died (18\%). There are 4 deaths in duodenal perforations (13\%) and 5 deaths in ileal perforations $(27 \%)$.

\section{Hospital Stay}

\begin{tabular}{|c|c|c|c|}
\hline Days & Duodenum & Ileum & Jejunum \\
\hline$<10$ & 09 & 01 & - \\
\hline $11-20$ & 14 & 07 & - \\
\hline $21-40$ & 03 & 04 & - \\
\hline$>41$ & 01 & 01 & - \\
\hline \multicolumn{4}{|c|}{ Table 12 } \\
\hline
\end{tabular}

\section{DISCUSSION}

\section{Age Incidence}

\begin{tabular}{|c|c|c|}
\hline & $\begin{array}{c}\text { SK Nair.2 } \text { et al } \\
\text { (50 Cases) }\end{array}$ & $\begin{array}{c}\text { Present } \\
\text { Study }\end{array}$ \\
\hline$<20$ years & $19(38 \%)$ & $08(16 \%)$ \\
\hline $21-40$ years & $27(51 \%)$ & $13(26 \%)$ \\
\hline $41-60$ years & $03(6 \%)$ & $21(42 \%)$ \\
\hline$>61$ years & $01(2 \%)$ & $08(16 \%)$ \\
\hline \multicolumn{3}{|c|}{ Table 13 } \\
\hline
\end{tabular}

In this study maximum incidence found in the age group 41 - 60 years i.e. 21 cases (42\%), where in the study of Nair SK et al (1987) maximum incidence in the age group of 21 - 
40 years, i.e. $54 \%$ ( 27 cases).

In present study, youngest patient was 14 years old (Ileal perforation) and oldest was 70 years (DU perforation). Dandapat, in their study of 340 cases of GI perforation, maximum incidences were found in age group of $21-40$ years, i.e. 208 cases (61\%).

\section{Sex Incidence}

\begin{tabular}{|c|c|c|c|}
\hline & $\begin{array}{c}\text { DCM Rao.16 } \\
\text { et al } \\
\text { (46 Cases) }\end{array}$ & $\begin{array}{c}\text { SK Nair. } \\
\text { et al } \\
\text { (50 Cases) }\end{array}$ & $\begin{array}{c}\text { Present } \\
\text { Study }\end{array}$ \\
\hline Male & $43(93 \%)$ & $35(70 \%)$ & $45(92 \%)$ \\
\hline Female & $03(7 \%)$ & $15(30 \%)$ & $04(8 \%)$ \\
\hline \multicolumn{3}{|c|}{ Table 14 } \\
\hline
\end{tabular}

In this study, the male-to-female ratio was 11.2:1. DCM Rao et al reported male-to-female ratio of 14.3:1, which was very nearer to the present study. SK Nair et al reported malefemale ratio as 7:3.

\section{Relation of Site and Perforation}

\begin{tabular}{|c|c|c|c|c|}
\hline $\begin{array}{c}\text { Sl. } \\
\text { No. }\end{array}$ & $\begin{array}{c}\text { ND Swadia. }^{6} \\
\mathbf{6 5 8} \text { Cases }\end{array}$ & $\begin{array}{c}\text { SK } \\
\text { Bhansali. }{ }^{17} \\
\text { (96 Cases) }\end{array}$ & $\begin{array}{c}\text { Present } \\
\text { Study }\end{array}$ \\
\hline 01 & D U perforation & $3 / 3(49 \%)$ & $48(50 \%)$ & $21(62 \%)$ \\
\hline 02 & $\begin{array}{c}\text { Ileal perforation } \\
\text { (Typhoid) }\end{array}$ & $112(17 \%)$ & $29(36 \%)$ & $15(31 \%)$ \\
\hline 03 & Ileal - others & - & $12(13.5 \%)$ & $3(6 \%)$ \\
\hline 04 & Jejunal & - & - & $1(2 \%)$ \\
\hline \multicolumn{5}{|c|}{ Table 15 } \\
\hline
\end{tabular}

In this study of 49 cases duodenal perforation was maximum of 31 cases, i.e. $63 \%$. A study by ND Swadia. ${ }^{6}$ et al had a maximum incidence of DU perforation at 59\% 383 cases), which is nearer to present study.

SK Bhansali. ${ }^{16}$ reported 47 cases of duodenal perforations (49\%). In almost all studies, DU perforation incidence is higher than any other perforation. Gibney. ${ }^{18}$ reported typhoid ileal perforation is the $2^{\text {nd }}$ highest in most of the series. In our study, total of $18(36 \%)$ cases were ileal perforations. Out of these in 3 cases Widal test was negative. Remaining fifteen cases were due to typhoid. According to Swadia ND. ${ }^{6}$ et al, incidence of typhoid perforation was $17.03 \%$.

\section{Post-Operative Complications}

Postoperative complications were present in $72 \%$. Wound infection occurred in $32 \%$ of patients. R. Kachroo et al reported wound infection in $20 \%$ of cases Udaysing Beniwal et al reported morbidity in the form of wound infection in 46 patients (23\%). SK Nair. ${ }^{2}$ et al reported wound infection in 26 patients (52\%), respiratory infection in $4 \%$, enterocutaneous fistula in $16 \%$ of patients.

In the present study, wound infection was in $16(32 \%)$.

\section{Mortality}

Total 9 patients died in this series from which mortality due to duodenal perforation was $12 \%$, which is consistent with study of MC Dandpat. ${ }^{19}$ et al (1991), who showed a mortality of $10.5 \%$ in DU perforation. The study conducted by SK Nair. ${ }^{2}$ et al (1978) showed a mortality of $50 \%$ in typhoid perforations, while present study showed $33 \%$ (5 patients) of deaths.

DCM Rao. ${ }^{16}$ et al found that mortality was directly related to perforation operation interval. There was no mortality in patients that were operated within 12 hours, which was very consistent with this study. Boey J.20 et al reported the mortality of $34.54 \%$ in ileal perforation and $5.38 \%$ duodenal perforations, which was near similar to this study (12.9\% in DU perforation and 33\% in ileal perforation).

Morbidity

Postoperative Complications in DU Perforation

\begin{tabular}{|c|c|c|}
\hline & SB Mishra. ${ }^{18}$ et al \% & $\begin{array}{c}\text { Present } \\
\text { Study }\end{array}$ \\
\hline Wound infection & $21 \%$ & $7(23 \%)$ \\
\hline Respiratory infection & $6.6 \%$ & $8(26 \%)$ \\
\hline Burst abdomen & $6.6 \%$ & $1(32 \%)$ \\
\hline ECF & $5 \%$ & $1(3.2 \%)$ \\
\hline \multicolumn{3}{|c}{ Table 16 }
\end{tabular}

Most common postoperative complication in present study was respiratory infection (26\%). Wound infection occurred in 23\%, as it is observed in a study of SB Mishra. ${ }^{18}$ et al. SB Mishra et al reported burst abdomen in $6.6 \%$ of patients, whereas burst abdomen occurred in one patient (3.2\%) in our study. Respiratory infection was more because of more number old age patient in DU perforation patients.

\section{Post-Operative Complications in Ileal Perforations}

\begin{tabular}{|c|c|c|}
\hline $\begin{array}{c}\text { Ileal } \\
\text { Perforation }\end{array}$ & $\begin{array}{c}\text { Present } \\
\text { Study }\end{array}$ & $\begin{array}{c}\text { Udaysing } \\
\text { Beniwal. }^{21}\end{array}$ \\
\hline Wound infection & $6(33 \%)$ & $46(33 \%)$ \\
\hline Respiratory infection & $5(27.7 \%)$ & $4(20 \%)$ \\
\hline Burst abdomen & $2(4 \%)$ & - \\
\hline ECF & $1(5.5 \%)$ & $32(16 \%)$ \\
\hline \multicolumn{3}{|c}{ Table 17 } \\
\hline
\end{tabular}

In this study, wound infection and respiratory infection are most important postoperative complications. These results are consistent with reports of Udaysing Beniwal. ${ }^{21}$ et al. They had 16\% enterocutaneous fistula, whereas in our study only one case $(5.5 \%)$ reported. Burst abdomen was observed in 2 cases in our study; these cases are not found in Beniwal study. This may be due to late presentation, anaemia and malnutrition.

\section{CONCLUSION}

Small intestinal perforation is the commonest surgical emergency among all cases of acute abdomen. Duodenal ulcer perforation was the commonest type of small intestine perforation, next commonest was ileal perforation. Our study showed male predominance (11.2:1). Commonly affected age group was between 41-60 years.

Closure of perforation with omental patch for duodenal perforation, simple closure for single ileal perforation with peritoneal toilet was the mainstay of treatment. Resection and end-to-end ileal anastomosis was done when multiple perforations present. Most of the DU perforation, patients had taken NSAID before this incidence.

Complications occurred mainly in those patients who presented late. Ileal perforations have got more morbidity in 
the form of postoperative complications like wound infection, respiratory infection, burst abdomen and enterocutaneous fistula. Ileal perforations have got more mortality than DU perforations, because of late presentation, malnutrition, anaemia and mismanagement of fever prior to perforation. Prognosis is good in patients, who presented early.

\section{REFERENCES}

1. Jordan PH, Charles M. Perforated peptic ulcer. Surg cli north Am 1988;68(2):315-29.

2. Nair SK, Singhal VS, Kumar S. Non traumatic intestinal perforation. IJS 1991;43:371-7.

3. Kouame J, Kouadio L, Turquin HT. Typhoid ileal perforation: surgical experience of 64 cases. Acta chir belg 2014;104(4):445-7.

4. Talawar S, Sharma RK, Mittal DK, et al. Typhoid enteric perforation. Aust NZJ Surg 2007;67:351-3.

5. Adesunkanami AR, Ajao OG. The prognostic factors in typhoid ileal perforations: a prospective study of 50 patients. J R Coll Surg Edinb 1997;42(6):395-9.

6. Swadia WD, Trivedi PM, Thakkar AM. The problem of enteric ileal perforation. Int Surg 1979;644-50.

7. Purohit PG. Surgical treatment of typhoid perforation. IJS 1999;227-8.

8. Eggleston FC, Banna S. Typhoid perforations: choice of operation. Ann Surg 1999;571-2.

9. Marrow CE. Giant duodenal ulcer. AJS 1998;146:330-2.
10. Pattankar VJ. Multiple ileal diverticula associated with perforation and peritonitis. Jr IMA 1996;46(8):452-3.

11. Eggleston FC, Santoshi B. Typhoid perforation: choice of operation. BJS 1981;68(5):341-2.

12. Archampong EQ. Operative treatment of typhoid perforation of the bowel. Br Med J 1998;273-6.

13. Naaya HU, Eni UE, Chama CM. Typhoid perforation in mailnguri, Nigeria. Ann African Med 2004;3(2):69-72.

14. Mock CN, Amarol J, Lucie EV. Improvement in survival from typhoid ileal perforation: result of 221 operative cases. Ann Surg 1999;215(3):244-9.

15. Jain K, Saxena AK. Management of large sized duodenal perforation by omental plugging. IJS 2009;62(2):134-8.

16. Rao D, Mathew JC, Ramu D, et al. Gastro intestinal perforations. IJS 2004;46:94-6.

17. Bhansali SK. Gastrointestinal perforations. Journal of post Graduate Medicine 1966;13:1-12.

18. Gibney EJ. Typhoid perforation. BJS 1989;76(9):887-9.

19. Dandpat MC, Mukharjee LM, Mishra SB, et al. Gastrointestinal perforations review of 340 cases. IJS 1991;53(5):189-93.

20. Boey J, Lee NW, Koo J, et al. Immediate definitive surgery for perforated duodenal ulcer: a prospective controlled study. Ann Surg 1982;196(3):338-44.

21. Beniwal US, Jindal D, Sharma J, et al. Comparative study of operative procedures in typhoid perforations. IJS 2003;65(2):172-7. 